\title{
TELAAH FAKTOR-FAKTOR YANG MEMPENGARUHI STATUS GIZI BALITA DI KOTA PADANG BERDASARKAN BERAT BADAN PER TINGGI BADAN MENGGUNAKAN METODE CART
}

\author{
Izzati Rahmi H.G ${ }^{1 *}$, HazmiraYozza ${ }^{2}$, Hafifatul Auliya Rahmy ${ }^{3}$ \\ 1-2 Jurusan Matematika, FMIPA, Universitas Andalas \\ ${ }^{3}$ Jurusan Nutrisi, Fakultas Kesehatan Masyarakat, Universitas Andalas \\ izzatirahmihg@gmail.com, hyozza@gmail.com,rauliyabee@gmail.com
}

\begin{abstract}
This study was conducted to determine factors that affect the nutritional status of children under 5 years of age in Padang City West Sumatra based on weight-for-height using Classification and Regression Tree (CART). The study was carried out in 4 districts in Padang City. A Total of 311 under 5 years of age children was examined. Children nutritional status are assess using weight-for-height $\mathrm{Z}$ score complied with WHO standard for children growth. Factors those were hypothesized to influence children nutritional status were gender, age, family income, maternal education level, number of children and score of maternal knowledge about nutrition. Data were analyzed using tree classification methods namely CART method. It was found that there were 3 variables that affect children nutritional status i.e age, family income and maternal knowledge about nutrition.
\end{abstract}

Keywords: nutritional status, below-5-years, weight-for-lenght, CART

\section{PENDAHULUAN}

Masalah gizi merupakan salah satu aspek penting yang sangat mempengaruhi derajat kesehatan masyarakat.Kualitas sumber daya manusia dimasa yang akan datang sangat dipengaruhi oleh status gizi. Kekurangan gizi dapat menimbulkan masalah kesehatan (morbiditas, mortalitas dan disabilitas) dan menurunkan kualitas sumber daya manusia.Dalam skala yang lebih luas, kekurangan gizi dapat menjadi ancaman bagi ketahanan dan kelangsungan hidup suatu bangsa.

Balita merupakan kelompok usia yang paling rentan mengalami masalah gizi buruk. Kurang gizi pada balita dapat berakibat gagal tumbuh kembang serta meningkatkan kesakitan dan kematian.
Bila balita mengalami gizi buruk, maka perkembangan otak tidak optimal dan berpengaruh kepada kehidupannya di masa yang akan datang (Marmi, 2013).

Secara nasional, prevalensi berat-kurang (BB/U) pada tahun 2013 adalah 19,6 persen, terdiri dari 5,7 persen gizi buruk dan 13,9 persen gizi kurang. Angka ini meningkat jika dibandingkan dengan angka prevalensi di tahun 20107 sebesar 18,4 \% dan 17,9\% pada tahun 2010 (Riskesdas 2013). Hasil Riskesdas 2013 juga menunjukkan bahwa, diantara 33 provinsi di Indonesia, Sumatera Barat berada pada urutan ke-18 prevalensi gizi buruk-kurang menurut $\mathrm{BB} / \mathrm{U}$.

Masih tingginya persentase balita yang mengalami masalah gizi, tentunya 
perlu mendapat perhatian serius mengingat balita adalah usia yang sangat rentan untuk mengalami masalah gizi. Untuk itu pada tahap awal perlu diidentifikasi faktor-faktor yang mempengaruhi masalah gizi pada balita. Selanjutnya perlu dilakukan evaluasi terhadap kebijakan terkait perhatian terhadap masalah gizi balita.

Terdapat beberapa indikator yang dapat digunakan untuk menilai staus gizi balita. Indikator-indikator tersebut adalah berat badan per umur $(\mathrm{BB} / \mathrm{U})$, tinggi badan per umur $(\mathrm{TB} / \mathrm{U})$, berat badan per tinggi $(\mathrm{BB} / \mathrm{TB})$ atau indikator-indikator lain. Dalam penilaian status gizi, nilainilai ini dibandingkan dengan sebuah rujukan pada balita yang mendapatkan nutrisi dengan baik.

Banyak faktor yang dapat mempengaruhi gizi balita.UNICEF menjelaskan beberapa tahapan penyebab timbulnya kurang gizi pada anaka balita yang dibagi menjadi penyebab langsung, tidak langsung, penyebab pokok, dan akar masalah.Penyebab langsung adalah asupan makanan dan infeksi penyakit.Faktor tidak langsung adalah ketahanan pangan, pola pengasuhan, serta pelayanan kesehatan lingkungan.Ketiga faktor tidak langsung ini berkaitan dengan tingkat pendidikan, pengetahuan dan keterampilan keluarga.(Almatsier, 2009).

Mengingat banyaknya faktorfaktor yang mempengaruhi status gizi balita, maka pada penelitian ini akan digunakan metode klasifikasi berstruktur pohon untuk memodelkan status gizi balita. Metode ini merupakan salah satu metode yang sangat direkomendasikan untuk mengkaji hubungan antara peubah dependen dan peubah independen ketika data yang dianalisis memiliki kompleksitas yang tinggi yaitu jumlah observasi yang besar atau jumlah peubah yang banyak. Terdapat beberapa metode klasifikasi berstruktur pohon, dan pada penelitian ini akan digunakan Metode CART.

Penelitian ini bertujuan untuk mengidentifikasikan variabel-variabel yang mempengaruhi status gizi balita di Kota padng berdasarkan indikator BB/TB menggunakan ,etode klasifikasi pohon dengan metode CART.

\section{STATUS GIZI BALITA}

Gizi adalah suatu proses menggunakan makanan yang dikonsumsi secara normal melalui proses digesti, absorpsi, transportasi, penyimpanan, metabolisme dan pengeluaran zat-zat yang tidak digunakan untuk mempertahankan kehidupan, pertumbuhan dan fungsi normal dari organ-organ serta menghasilkan energi.

Status gizi adalah keadaan akibat dari keseimbangan antara konsumsi dan penyerapan gizi dan penggunaan zat gizi tersebut atau keadaan fisiologi akibat dari tersedianya zat gizi dalam sel tubuh (Supariasa, 2002).Jadi, status gizi merupakan keadaan tubuh sebagai akibat konsumsi makanan dan penggunaan zat gizi.Status gizi merupakan cerminan ukuran terpenuhinya kebutuhan gizi.

Konsep terjadinya keadaan gizi mempunyai faktor dimensi yang sangat kompleks.Faktor-faktor yang mempengaruhi keadaan gizi yaitu konsumsi makanan dan tingkat kesehatan.Konsumsi makanan dipengaruhi oleh pendapatan, makanan, dan tersedianya bahan makanan (Supariasa, 2002).

Masalah gizi anak secara garis besar merupakan dampak dari 
ketidakseimbangan antara asupan dan keluaran zat gizi (nutritional imbalance), yaitu asupan yang melebihi keluaran atau sebaliknya, di samping kesalahan dalam memilih bahan makanan untuk disantap (Arisman, 2009).

\section{PENILAIAN STATUS GIZI BALITA} Penilaian Status Gizi (PSG) adalah sebuah metode mendeskripsikan kondisi tubuh sebagai akibat keseimbangan makanan yang dikonsumsi dengan penggunaannya oleh tubuh, yang biasanya dibandingkan dengan suatu nilai normatif yang ditetapkan (WHO, 2005).

Penilaian status gizi secara langsung dibagi empat penilaian yaitu antropometri, klinis, biokimia, dan biofisik. Masing-masing penilaian tersebut akan dibahas secara umum sebagai berikut.

\section{Antropometri}

Antropometri artinya ukuran tubuh manusia. Ditinjau dari sudut pandang gizi, antropometri berhubungan dengan berbagai macam pengukuran dimensi tubuh dan komposisi tubuh dari berbagai tingkat umur dan tingkat gizi.Antropometri secara umum digunakan untuk melihat ketidakseimbangan asupan protein dan energi.Ketidakseimbangan ini terlihat pada pola pertumbuhan fisik dan proporsi jaringan tubuh seperti lemak, otot dan jumlah air dalam tubuh.

\section{Klinis}

Metode ini didasarkan atas perubahanperubahan yang terjadi yang dihubungkan dengan ketidakcukupan zat gizi, dilihat pada jaringan epitel (supervicial epithelial tissues) seperti kulit, mata, rambut dan mukosa oral atau pada organ-organ yang dekat dengan permukaan tubuh seperti kelenjar tiroid.Penggunaan metode ini umumnya untuk survei klinis secara cepat (rapid clinical surveys) yang dirancang untuk mendeteksi secara cepat tandatanda klinis umum dari kekurangan salah satu atau lebih zat gizi.

\section{Biokimia}

Penilaian status gizi secara biokimia dilakukan melalui pemeriksaan spesimen secara laboratoris yang dilakukan pada berbagai macam jaringan tubuh, seperti darah, urine, tinja, jaringan otot, hati.Metode ini digunakan untuk suatu peringatan kemungkinan akan terjadi keadaan malnutrisi yang lebih parah lagi.

\section{Biofisik}

Pada metode ini, status gizi dinilai dengan melihat kemampuan fungsi (khususnya jaringan) dan melihat perubahan struktur dari jaringan.Metode ini secara umum digunakan dalam situasi tertentu seperti kejadian buta senja epidemik (Supariasa, 2002).

Dengan antropometri, status gizi balita diukur dengan indeks antropometri $\mathrm{BB} / \mathrm{U}$, TB/U, dan BB/TB. Berat badan adalah salah satu parameter yang memberikan gambaran massa tubuh. Massa tubuh sangat sensitif terhadap perubahan-perubahan yang mendadak, misalnya karena terserang penyakit infeksi, menurunnya nafsu makan atau menurunnya jumlah makanan yang dikonsumsi.Berat badan adalah parameter antropometri yang sangat labil.

Dalam keadaan normal, dimana
keadaan kesehatan baik dan
keseimbangan antara konsumsi dan
kebutuhan zat gizi terjamin, maka berat
badan berkembang mengikuti
pertambahan umur.Sebaliknya dalam


keadaan yang abnormal, terdapat 2 kemungkinan perkembangan berat badan, yaitu dapat berkembang cepat atau lebih lambat dari keadaan normal. Berdasarkan karakteristik berat badan ini, maka indeks berat badan menurut umur digunakan sebagai salah satu cara pengukuran statu gizi. Meningat karakteristik berat badan yang labil, maka indeks BB/U lebih menggambarkan status gizi seseorang saat ini (Supariasa, 2002).

Selain dengan $\mathrm{BB} / \mathrm{U}$, penilaian status gizi juga dapat dilakukan dengan indikator $\mathrm{BB} / \mathrm{TB}$. Penilaian status gizi dilakukan dengan terlebih dahulu menghitung nilai z-skor :

$Z-$ skor $=\frac{\left(\frac{B B}{T B} a k t u a,- \text { median rujukan }\right)}{\text { simpanganba.ku rujukan }}$

Berdasarkan nilai Z-Skor, balita dapat dikelompokkan ke dalam empat status gizi, yaitu :

1. Sangat Kurus : <-3 SD

2. Kurus $:-3$ SD s/d <-2 SD

3. Normal : $-2 \mathrm{SD}$ s/d $+2 \mathrm{SD}$

4. Gemuk : >+2 SD

\section{METODE CART}

\section{CART (Classification and} Regression Trees) merupakan salah satu metode atau algoritma dari salah satu teknik eksplorasi data yaitu teknik pohon keputusan. CART terbilang sederhana namun merupakan metode yang kuat. CARTbertujuan untuk mendapatkan suatu kelompok data yang akurat sebagai penciri dari suatu pengklasifikasian, selain itu CART digunakan untuk menggambarkan hubungan antara variable respon (variabel dependen atau tak bebas ) dengan satu atau lebih variabel prediktor (variabel independen atau bebas). Model pohon yang dihasilkan bergantung pada skala variable respon, jika variabel respon data berbentuk kontinu maka model pohon yang dihasilkan adalah regression trees (pohon regresi) sedangkan bila variabel respon mempunyai skalakategorik maka pohon yang dihasilkan adalah classification trees (pohonklasifikasi)[2].

\subsubsection{CART dalam Bidang Kesehatan}

CART secara statistik dapat menunjukkan faktor mana yang sangat penting dalam sebuah model atauhubungannya dalam hal kekuatan penjelas dan varians. Proses iniidentik dengan teknik regresi yang diketahui sebelumnya, namun menyajikan data dengan cara yang mudahditafsirkan oleh mereka yang tidak berpengalaman dalam analisis statistik. Dengan cara ini, CARTmenyajikan sebuah potret canggih dari hubungan variabel dalam data dan bisa dijadikan langkah awal dalam membangun model informatif atau visualisasi akhir dari asosiasi penting.Dalam proyek kesehatan masyarakat yang besar, ahli statistik dapat menggunakan CART untuk menyajikan data awal atau pemangkukepentingan proyek lain yang dapat mengomentari hasil statistik dengan praktikpengetahuan. Variabel dalam data pada akhirnya menghasilkan informasi yang lebih baik dan informatif secara statistikmodel daripada pendekatan klinis atau statistik tunggal. Manfaat CART adalah untuk menjembatani interpretasi dan ketepatan statistiksecara visual serta memudahkandesain model yang relevan dan valid.

CART mungkin tidak dikenal di beberapa bidang kesehatan, tapi konsepnya kuatberakar pada praktik 
kesehatan, terutama di bidang epidemiologi dan klinis. Analisis CART bisa membimbing peneliti medisuntuk mengisolasi variabel mana yang paling penting sebagai tempat intervensi potensial.Penelitian mengenai faktor perilaku, sering memiliki beberapa intuisitentang prediktor yang paling penting, yang mungkin menjelaskan mengapa metode ini sering dilakukan pada bidang kesehatan masyarakat [9].

\subsubsection{Pohon CART}

Pohon keputusan dibentuk dengan menggunakan algoritma penyekatan rekursif secara biner (binery recursive partitioning).Pemilahan dilakukan untuk memilah data menjadi 2 kelompok, yaitu kelompok yang masuk simpul kiri dan yang masuk simpul kanan.Pemilahan dilakukan pada tiap simpul sampai didapatkan suatu simpul terminal/akhir.Variabel yang memilah pada simpul utama adalah variable terpenting dalam menduga kelas dari amatan.

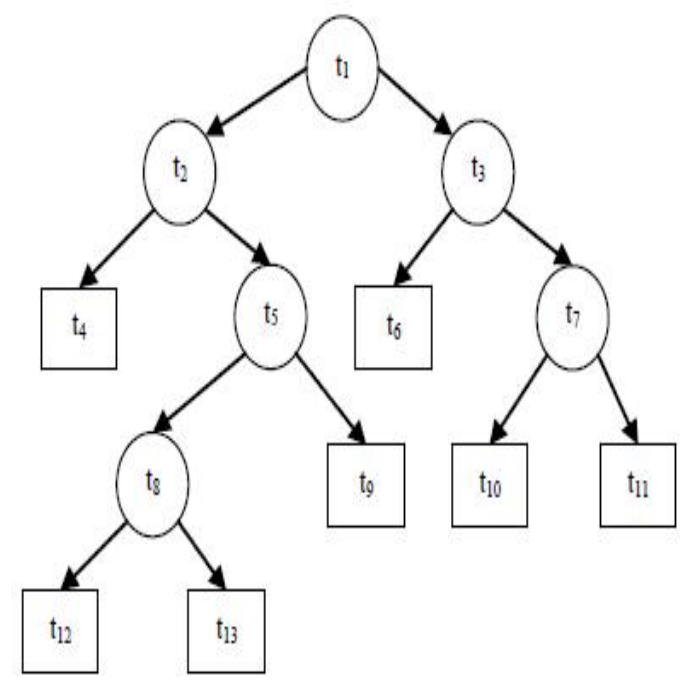

Gambar : Struktur Pohon CART Simpul utama (root node) dinotasikan sebagai $t_{1}$, sedangkan simpul $\mathrm{t}_{2}, \mathrm{t}_{3}, \mathrm{t}_{5}, \mathrm{t}_{7}$ dan $\mathrm{t}_{8}$ disebut simpul dalam (internal nodes).Simpul akhir yang juga disebut sebagai simpul terminal (terminal nodes) adalah $\mathrm{t}_{4}, \mathrm{t}_{6}, \mathrm{t}_{9}, \mathrm{t}_{10}, \mathrm{t}_{11}, \mathrm{t}_{12}$ dan $\mathrm{t}_{13}$ dimana tidak terjadi lagi pemilahan.Kedalaman pohon (depth) dihitung dimulai dari simpul utama atau $\mathrm{t}_{1}$ yang berada pada kedalaman 1, sedangkan $t_{2}$ dan $t_{3}$ berada pada kedalaman 2.Begitu seterusnya sampai pada simpul terminal $\mathrm{t}_{12}$ dan $\mathrm{t}_{13}$ yang berada pada kedalaman 5 [12].

Beberapa tahapan metode CART dalam pembuatan pohon keputusan, yaitu sebagai berikut :

1. Pembentukan pohon keputusan Proses pembentukan pohon keputusan terdiri atas 3 tahapan, yaitu :

a. Pemilihan (Classifier)

Sampel data Learning ( $L$ ) yang masih bersifat heterogen digunakan untuk pembentukan pohon klasifikasi. Sampel tersebut akan dipilah berdasarkan aturan pemilahan dan criteria goodness-of-split dan pemilihan pemilah tergantung pada jenis variabel responnya.Metode pemilihan pemilah menggunakan Impurity measure $i(t)$ merupakan pengukuran tingkat keheterogenan suatu kelas dari suatu simpul tertentu dalam pohon klasifikasi yang dapat membantu menemukan fungsi pemilah yang optimal. Beberapa fungsi Impurity measure $i(t)$ adalah sebagai berikut :

a. Indeks Gini

$$
i(t)=\sum_{i \neq j} p(i \mid t) p(j \mid t)
$$

b. Indeks Informasi

$$
i(t)=-\Sigma_{j} p(j \mid t) \log [p(j \mid t)]
$$

c. Indeks Twoing 


$$
\begin{aligned}
& i(t)=\frac{v_{L} v_{R}}{4}\left[\sum \mid p\left(j \mid t_{L}\right)-\right. \\
& \left.\left.p\left(j \mid t_{R}\right) \mid\right]\right]^{-z}
\end{aligned}
$$

d. Indeks Entropi

$$
i(t)=N j(t) \log [p(j \mid t)](2.4
$$

Dalam penelitian ini digunakan Indeks Gini, dengan $p(i \mid t)$ adalah peluang kelas $i$ pada simpul $t$, dan $p(j \mid t)$ adalahpeluang kelas $j$ pada simpul $t$. Goodness of Split merupakan suatu evaluasi pemilahan oleh pemilah $s$ pada simpul $t$ yang didefinisikan sebagai penurunan keheterogenan dan didefinisikan sebagai :

$$
\begin{aligned}
& \emptyset(s, t)=\Delta i(s, t)=i(t)-p_{L} i\left(t_{L}\right)- \\
& p_{R} i\left(t_{R}\right)
\end{aligned}
$$

Dengan $p_{L} i\left(\boldsymbol{t}_{L}\right)$ adalah peluang pengamatan dari simpul $t$ menuju simpulkiri, dan $p_{R} i\left(t_{R}\right)$ adalah peluang pengamatan dari simpul tmenuju simpul kanan.Pemilah yang menghasilkan nilai lebih tinggi merupakan pemilah yang lebih baik karena hal ini memungkinkan untuk mereduksi keheterogenan secara lebih signifikan.sehingga ditemukan pemilah $s *$ yang memberikan nilai penurunan keheterogenan tertinggi yaitu :

$$
\Delta i\left(s *, t_{1}\right)=\max _{s \in s} \Delta i\left(s, t_{1}\right)
$$

Metode pemilahan yang sering digunakan adalah indeks Gini, hal tersebut dikarenakan lebih mudah dan sesuai untuk diterapkan dalam berbagai kasus dan mempunyai perhitungan yang sederhana dan cepat [2].

b. Penentuan simpul terminal Suatu simpul $t$ akan menjadi simpul terminal atau tidak,akan dipilah kembali bila pada simpul $t$ tidak terdapat penurunan keheterogenan secara berarti atau adanya batasan minimum $n$ seperti hanya terdapat satu pengamatan pada tiap simpul anak. Jumlah kasus minimum dalam suatu terminal akhir umumnya adalah 5, dan apabila hal itu terpenuhi maka pengembangan pohon dihentikan.

c. Penandaan label kelas

Penandaan label kelas pada simpul terminal dilakukan berdasarkan aturan jumlah terbanyak. Label kelas simpul terminal $t$ adalah $j_{0}$ yang memberi nilai dugaan kesalahan pengklasifikasian simpul $t$ terbesar. Proses pembentukan pohonberhenti saat terdapat hanya satu pengamatan dalam tiap tiap simpul anak atau adanya batasan minimum $n$, semua pengamatan dalam tiap simpul anak identik, dan adanya batasan jumlah level/kedalaman pohon maksimal.

$$
p\left(j_{0} \mid t\right)=\max _{j} p(j \mid t)=\max _{j} \frac{N_{j} t}{N(t)}
$$

Dengan

$p(j \mid t)$ : proporsi kelas $j$ pada simpul

$N_{j}(t)$ : jumlah pengamatan kelas $j$ pada simpul $t$

$N(t) \quad$ : jumlah pengamatan pada simpul $t$

\section{Pemangkasan pohon}

Proses pembentukan pohon berhenti saat terdapat hanya satu pengamatan dalam tiap simpul anak atau adanya batasan minimum $n$, semua pengamatan dalam tiap simpul anak identik, dan adanya batasan jumlah level/kedalaman pohon maksimal. Setelah terbentuk pohon maksimal tahap selanjutnya adalah pemangkasan pohon untuk mencegah terbentuknya pohon yang berukuran sangat besar dan kompleks, sehingga diperoleh ukuran pohon yang layak berdasarkan cost 
complexity prunning, maka besarnya resubtitution estimate pohon $T$ pada parameter kompleksitas a yaitu :

$$
R_{\alpha}(T)=R(T)+\alpha|\bar{T}|
$$

Dengan

$R_{\alpha}(T) \quad$ : resubsitution suatu pohon $T$ pada kompleksitas $\alpha$

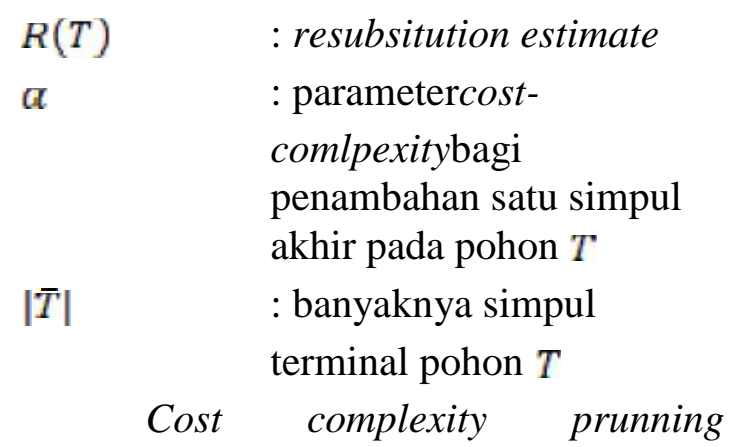
menentukan pohon bagian $T(\alpha)$ yang meminimumkan $R_{\alpha}(T)$ pada seluruh pohonbagian untuk setiap nilai $\alpha$. Nilai parameter kompleksitas aakan secara perlahan meningkat selama proses pemangkasan. Selanjutnya pencarian pohon bagian $T(\alpha)<T_{\max }$ dapat meminimumkan $R_{\alpha}(T)$ yaitu [13]:

$$
R_{\alpha}((T(\alpha)))=\min _{T<T_{\max }} R_{\alpha}(T)
$$

3. Penentuan pohon klasifikasi optimal

Ukuran pohon yang besar akan menyebabkan nilai kompleksitas yang tinggi karena struktur data yangdigambarkan cenderung komplek, sehingga perlu dipilih pohon optimal yang berukuran sederhana tetapi memberikan nilai penduga pengganti cukup kecil. Ada dua jenis penduga pengganti, penduga sampel uji (test sample estimate) dan penduga validasi silang lipat V (cross validation $V$-fold estimate). a. Penduga Sampel Uji (test sample estimate)

Penduga sampel uji L dibagi menjadi dua himpunan data,yaitu $\mathrm{L}_{1}$ (learning set) dan $\mathrm{L}_{2}$ (testing set). Data yang masuk ke dalam kelompok $\mathrm{L}_{1}$ digunakan untuk pembentukan pohon klasifikasi.Data yang masuk kedalam kelompok $\mathrm{L}_{2}$ digunakan untuk menduga $R^{\tau s}\left(T_{t}\right)$ dimana $\mathrm{N}_{2}$ adalah jumlah amatan dalamL $L_{2} \cdot R^{t s}\left(T_{t}\right)$ adalah total proporsi dari kesalahan klasifikasi pohon klasifikasi. Pohon optimal adalah $T^{*}$ yang memenuhi kriteria $R^{\tau s}\left(T_{t}\right)=\min R^{\tau s}\left(T_{t}\right)$.

Pohon optimal yang telah terbentuk dilakukan evaluasi dari hasil klasifikasi.Cara untuk mengevaluasi hasil klasifikasi adalah dengan menghitung akurasi klasifikasi.Sensitivity menggambarkan akurasi pada sampel kelas isedangkan specificity menggambarkan akurasi pada sampel kelas $j$. G-means dapat menggambarkan bagaimana sebuah metode klasifikasi mampu mengukur sensitivitydan specificity. Semakin besar nilai Gmeans menunjukkan metode klasifikasi tersebut mampu memprediksi data di tiap kelas dengan baik.

$1-\operatorname{APER}($ Tingkat Akuransi Total $)=$ $\frac{n_{11} n_{22}}{N}$

(2.4.11)

Total Tingkat Kesalahan $=\frac{n_{21} n_{12}}{N}$

Se $=\frac{n_{11}}{n_{: 1}}$

(2.4.13)

Sp $=\frac{n_{22}}{n_{22}}$

(2.4.14)

Keterangan : 
$n_{11}$ : jumlah observasi dari kelas 1 yang tepat diprediksi sebagai kelas 1

$\pi_{22}$ : jumlah observasi dari kelas 2 yang tepat diprediksi sebagai kelas 2 $n_{12}$ : jumlah observasi dari kelas 1 yang salah diprediksi sebagai kelas 2 $n_{21}$ : jumlah observasi dari kelas 2 yang salah diprediksi sebagai kelas 1

$\mathrm{N}_{1}$ : jumlah observasi dari kelas 1

$\mathrm{N}_{2 .}$ : jumlah observasi dari kelas 2

$\mathrm{N}$ : jumlah observasi

Se: Sensitivity (ketepatan klasifikasi

kelas 1 terhadap jumlah total observasi kelas 1)

$\varsigma p$ : Specificity (ketepatan klasifikasi

kelas 2 terhadap jumlah total observasi kelas 2)

b. Metode validasi silang

Metode validasi silang digunakan pada data yang berukuran kecil. Nilai V yang digunakan adalah 10 (10-fold cross validation). Metode validasi ini mengelompokkan data menjadi $\mathrm{D}_{1}, \mathrm{D}_{2}$, $\mathrm{D}_{3}, \ldots, \quad \mathrm{D}_{\mathrm{V}}$ yang masing-masingnya berukuran sama dan bersifat acak. $\mathrm{D}_{1}, \mathrm{D}_{2}$, $\mathrm{D}_{3}, \ldots, \mathrm{D}_{\mathrm{V}}$ ini disebut tests sets yang digunakan untuk validasi. $L_{\mathrm{V}}=D-D_{\mathrm{V}}$ dengan $V=1,2,3, \ldots . L_{V}$ disebut sebagai learning sets yaitu data yang digunakan untuk membangun pohon keputusan.Pohon optimum yang digunakan adalah pohon dengan kesalahan klasifikasi paling kecil [15].

\subsubsection{Pohon Klasifikasi ( Classification Tree)}

Jika variabel respon data berbentuk kategorik maka model pohon yang dihasilkan adalah pohon klasifikasi.Langkah-langkah untuk membuat pohon klasifikasi adalah :
1. CART memilah variable utama dari semua variable yang ada pada sampel. Pada tiap titik pemilahan pada variable terpilih, pilah sampel menjadi dua simpul. Tandai dengan "YA" pada pertanyaan di simpul kiri dan "TIDAK" pada pertanyaan di simpul kanan.

2. Gunakan criteria good-of-fitness pada tiap titik pemilahan dan evaluasi dengan menggunakan rumus impurity measure $(i(t))$ (menggunakan indeks Gini).

3. Variabel yang paling baik yang akan dipilih adalah variable dengan nilai impurity tertinggi.

4. Ulangi langkah 1-3 pada setiap variable yang tersisa pada simpul.

5. Rangking semua pemilahan terbaik dari tiap variable dengan menggunakan impurity measure.

6. Memilih variable dan titik pilah yang paling banyak tereduksi impurity dari simpul atau simpul induk.

7. Tetapkan klasifikasi simpulsimpul berdasarkan aturan pemangkasan pohon.

8. Ulangi langkah 1-7 pada tiap simpul anak yang bukan merupakan terminal.

9. CART dilanjutkan dengan proses pemilahan sehingga terbuat sebuah pohon klasifikasi [20].

\section{METODE PENELITIAN}

Populasi yang dipelajari pada penelitian ini adalah seluruh balita di Kota PadangData yang digunakan pada penelitian ini adalah data primer yang diperoleh melalui survei yang dilakukan 
terhadap populasi balita tersebut. Data dikumpulkan di beberapa posyandu, tempat penitipan anak dan perumahan di 4 kecamatan di kota Padang.

Variabel yang diamati meliputi

1. Berat badan balita

2. Tinggi balita

3. Keadaan sosial demografi balita dan keluarga, meliputi :

a. Umur balita

b. Jenis kelamin balita

c. Status Pekerjaan ibu yang dikategorikan menjadi bekerja dan tidak bekerja

d. Tingkat pendidikan ibu yang dibagi menjadi dua kategori, yakni pendidikan rendah, menengah dan tinggi

e. Banyak anak dalam keluarga

f. Penghasilan keluarga, dibagi ke dalam 3 kategori, penghasilan kurang dari 1 juta, penghasilan antara 2-5 juta dan penghasilan lebih dari 5 juta.

Pengambilan sampel dilakukan secara purposive.Pengukuran tinggi badan dan berat badan balita diukur langsung oleh surveyor. Berdasarkan nilai $\mathrm{BB}$ dan $\mathrm{TB}$ tersebut, dilakukan penilaian status gizi balita dengan terlebih dahulu mentransformasi nilai $\mathrm{BB} / \mathrm{TB}$ dengan

$$
\bar{Z}-\text { skor }=\frac{\left(\frac{B E}{T B} \text { aktua } ;- \text { median rujukan }\right)}{\text { simpangan baku rujukan }}
$$

Berdasarkan nilai z-skor, balita dikelompokkan ke dalam 4 status gizi, yaitu sangat kurus, kurus, normal dan gemuk.

Variabel-variabel lain dikumpulkan dengan membagikan kuesioner kepada ibu balita. Adapun skor pengetahuan ibu mengenai gizi balita diperoleh melalui beberapa pertanyaan mengenai gizi, termasuk pengetahuan ibu mengenai ASI ekslusif, pemberian vitamin A, penimbangan bayi serta pengetahuan-pengetahuan lain mengenai gat gizi.

Analisis terhadap data dilakukan dengan menggunakan Metode Klasifikasi Berstruktur Pohon.Pengolahan data dilakukan dengan menggunakan paket statistika SPSS.

\section{HASIL DAN PEMBAHASAN}

\section{Eksplorasi Data}

Data yang digunakan pada penelitian ini terdiri dari 311 pengamatan. Pada tabel berikut ini ditampilkan sebaran balita berdasarkan statust gizinya

Tabel 1.

Sebaran balita menurut Status Gizi

\begin{tabular}{|l|l|l|}
\hline Status Gizi & Jumlah & Persentase \\
\hline Sangat kurus & 45 & 14,5 \\
\hline Kurus & 54 & 17,4 \\
\hline Normal & 140 & 45,0 \\
\hline Gemuk & 72 & 23,2 \\
\hline Total & 311 & 100,0 \\
\hline
\end{tabular}

Pada tabel tersebut, dapat dilihat bahwa sebahagian besar balita di kota Padang dikategorikan sebagai balita dengan status gizi yang normal dan gemuk. Namun, masih cukup banyak (sekitar 14,5\%) balita mengalami masalah gizi yakni balita yang dikategorikan 


\section{Eksakta Vol. 18 No. 2 Oktober $\mid 2017$}

E-ISSN : 2549-7464, P-ISSN : 1411-3724

sebagai balita dengan status gizi sangat kurus.

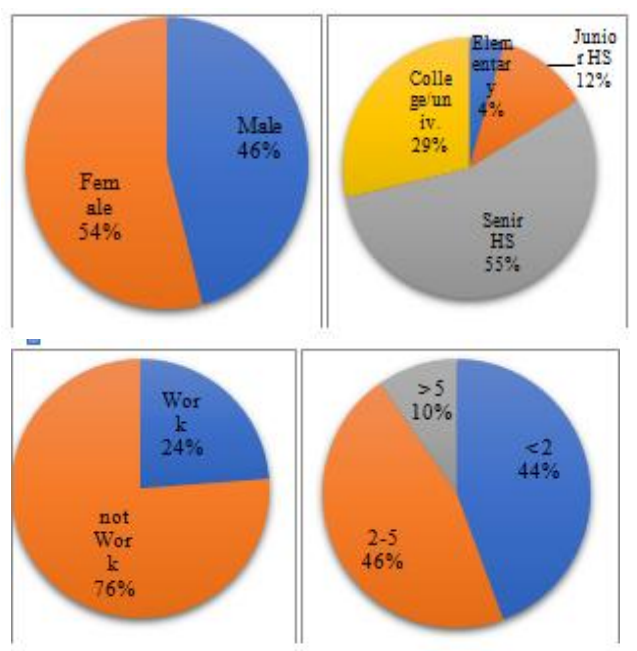

Gambar 1. Diagram Lingkaran Variabel Prediktor

Keterangan

a. Jenis kelamin b. Pendidikan Ibu

c. Status Pekerjaan Ibu d Penghasilan

Pada Gambar 1 disajikan diagram lingkaran untuk menggambarkan sebaran bayi berdasarkan empat variabel prediktor yang bertipe kategorik, yaitu jenis kelamin balita, tingkat pendidikan ibu, penghasilan keluarga dan status pekerjaan ibu.

Dari tabel tersebut, diketahui bahwa dari 311 orang balita, 54\% di antaranya adalah perempuan. Sekitar $55 \%$ balita memiliki ibu berpendidikan SMA dan hanya $4 \%$ yang berpendidikan SD/SMP.

Selanjutnya, dapat dilihat juga, dari 311 orang balita tersebut, sekita $24 \%$ ibu bekerja dan $76 \%$ ibu tidak bekerja. Dapat diketahui juga bahwa $44 \%$ balita berasal dari keluarga dengan penghasilan rendah, kurang dari 2 juta rupiah/bulan, sementara $46 \%$ balita berasal dari keluarga dengan penghasilan antara 2-5 juta rupiah/bulan.
Selanjutnya akan diperiksa keterkaitan antara variabel-variabel prediktor tersebut dengan status gizi balita dengan menggunakan uji Khi Kuadrat. Uji ini dilakukan untuk meperkirakan hubungan antar status gizi dengan masing-masing variabel prediktor kategorik.

Tabel 2.

Hasil Pengujian Khi-Kuadrat

\begin{tabular}{|l|l|l|l|}
\hline Variabel & $\chi^{2}$ & $\mathrm{p}$-val & Kesimpulan \\
\hline $\begin{array}{l}\text { Jenis kelamin vs } \\
\text { Status Gizi }\end{array}$ & 0,335 & 0,953 & Saling bebas \\
\hline $\begin{array}{l}\text { Pendidikan Ibu vs } \\
\text { status gizi }\end{array}$ & 9,773 & 0,369 & Saling bebas \\
\hline $\begin{array}{l}\text { Pekerjaan Ibu vs } \\
\text { Status Gizi }\end{array}$ & 6,693 & 0,094 & $\begin{array}{l}\text { Tidak Saling } \\
\text { bebas }\end{array}$ \\
\hline $\begin{array}{l}\text { Penghasilan Seluarga vs Status } \\
\text { Gizi }\end{array}$ & 11,757 & 0,072 & $\begin{array}{l}\text { Tidak Saling } \\
\text { bebas }\end{array}$ \\
\hline
\end{tabular}

Pada tabel 2 disajikan hasil pengujian hipotesis mengenai kebebasan variabel status gizi dengan 4 variabel prediktor yang bertipe kategorik.Pengujian dilakukan dengan menggunakan statistik khi-kuadrat.Kedua variabel dikatakan tidak saling bebas jika nilai-p yang diperoleh lebih dari taraf nyata yang digunakan.

Dari tabel tersebut diketahui bahwa dengan menggunakan taraf nyata $10 \%$, nilai $\mathrm{p}<10 \%$ ditemui pada pengujian terhadap status gizi vs status pekerjaan ibu dan status gizi vs penghasilan keluarga.Dengan demikian, dapat diperkirakan, kedua variabel inilah mungkin pada analisis selanjutnya sebagai variabel yang mempengaruhi status gizi balita.

\section{Hasil Analisis Klasifikasi Pohon}

Berikut ini akan diuraikan hasil pemodelan yang dilakukan terhadap 


\section{Eksakta Vol. 18 No. 2 Oktober $\mid 2017$}

E-ISSN : 2549-7464, P-ISSN : 1411-3724

hubungan status gizi dengan usia balita, jenis kelamin balita serta variabel sosiodemografi balita dan keluarga dengan

Diagram pohon yang dihasilkan menggunakan metode klasifikasi pohon CART.

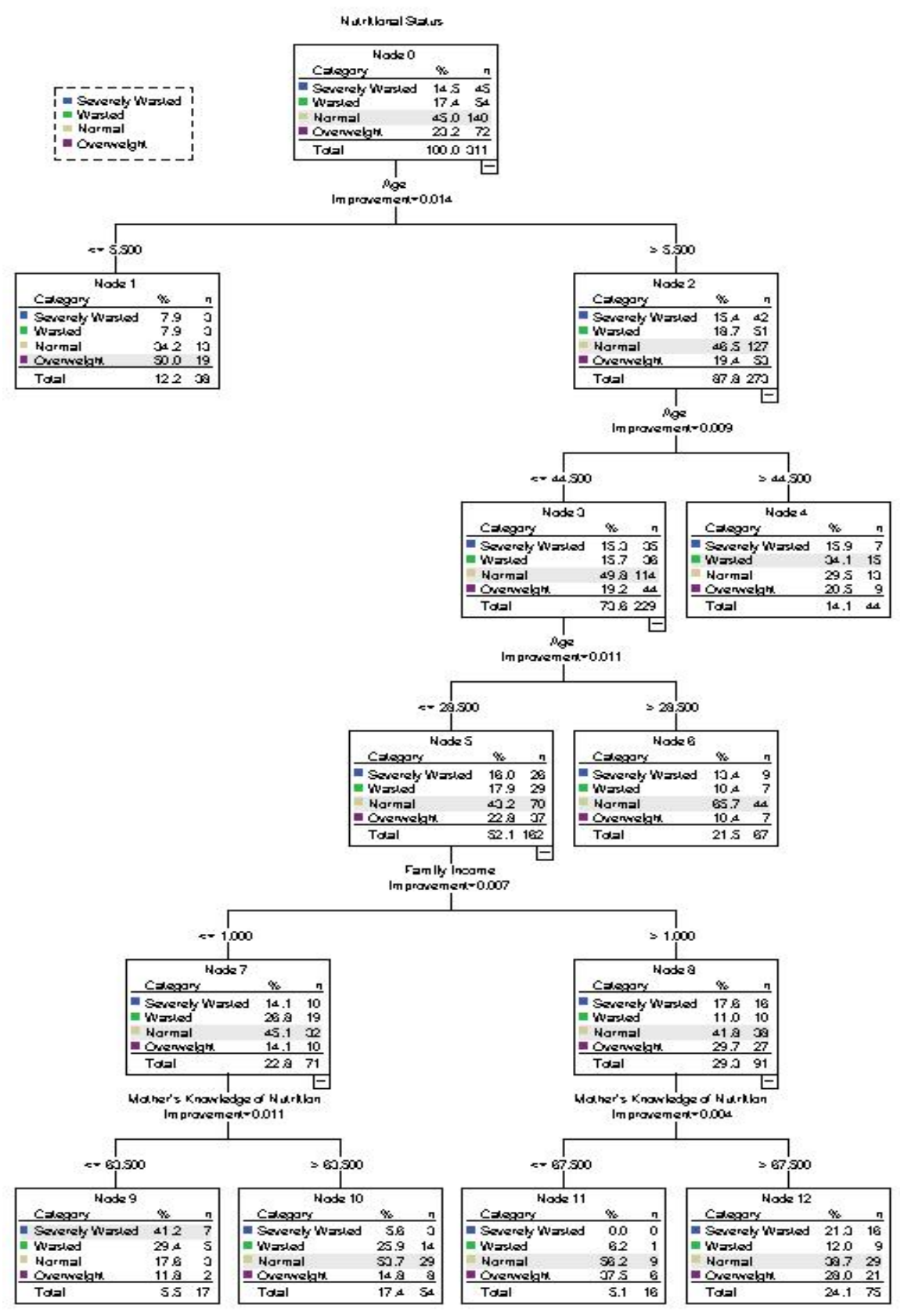


Gambar 3. Diagram Pohon

Pada gambar ini, diketahui bahwa simpul akar (simpul 0) berisi 311 data pengamatan yang selanjutnya secara rekursif akan disekat menjadi dua simpul anak. Terdapat 3 variabel yang muncul dalam proses penyekatan tersebut, yakni variabel umur balita, pendapatan keluarga dan pengetahua ibu mengenai gizi. Hal ini berarti bahwa ketiga variabel inilah yang dapat dipandang sebagai variabel yang berpengaruh terhadap status gizi balita pada penelitian berdasarkan indikator $\mathrm{BB} / \mathrm{TB}$.

Adapun variabel-variabel lain yang di awal diperkirakan juga mempengaruhi status gizi balita di Kota Padang, seperti tingkat pendidikan ibu, status pekergaan ibu, jenis kelamin balita tidak dapat dipandang sebagai vaiabel yang membedakan status gizi balita di Kota Padang.

Selanjutnya, dari tabel tersebut juga terlihat bahwa algoritma CART pada kasus ini menghasilkan 6 simpul akhir. Dengan demikian, berdasarkan hasil ini, balita pada penelitian ini dapat dikelompokkan ke dalam 6 kelompok, yakni : :

1. Balita dengan usia kurang dari 5,5 bulan. Balita pada kelompok ini memiliki peluang yang lebih besar berada pada status gizi gemuk

2. Balita usia di atas 44,5 bulan, dimana balita dengan karakteristik seperti ini cendrung kurus.
3. Balita usia 28,5 - 44,5 bulan yang diduga berada pada status gizi normal

4. Balita usia 5,5 - 28,5 bulan dan berasal dari keluarga dengan penghasilan lebih dari 2 million per month. Balita pada kategori ini juga cendrung berada pada status gizi normal

5. Balita berusia 5,5 - 28,5 bulan, berasal dari keluarga dengan penghasilan kurang dari 2 juta rupiah/bulan dan ibu hanya memiliki sedikit pengetahuan mengenai gizi. Balita pada kategori ini cendrung diduga mengalami gizi buruk dengan status gizi sangat kurus.

6. Balita usia 5,5 - 28,5 bulan, berasal dari keluarga dengan penghasilan kurang dari 2 juta rupiah per bulan namun ibu memiliki pengetahua yang baik mengenai gizi. Balita pada kelompok ini cendrung berada pada status gizi normal

\section{Pembahasan}

Berdasarkan hasil yang telah didapat sebelumnya, diketahui bahwa pengetahuan ibu mengenai gizi adalah salah satu variabel penting yang berperan terhadap status gizi balita di Kota Padang.Kejadian balita yang sangat kurusditemukan pada pada balita yang 
berasal dari keluarga dengan penghasilan yang rendah dan ibu dengan pengetahuan ibu yang kurang mengenai gizi.Sementara ibu dengan pengetahua yang cukup mengenai gizi cendrung memiliki bayi dengan status gizi normal.

Berdasarkan fakta tersebut, dapat dikatakan bahwa untuk mengurangi prevalensi kejadian status gizi sangat kurus, harus diupayakan peningkatan pengetahuan ibu mengenai gizi keluarga. Salah satu cara yang dapat dilakukan pemerintah adalah mengan meningkatkan keaktifan dan partisipasi masyarakat dalam posyandu.

Posyandu, disingkat dari Pos Pelayanan Terpadu, adalah program pemerintah Indonesia yang menyediakan pelayanan kesehatan terpadu berbasis masyarakat.Posyandu ini dilaksanakan dengan melibatkan masyarakat secara aktif dalam kegiatnnya dengan bimbingan dari tenaga kesehatan.Posyandu menyediakan pelayanan kesehatan bagi bayi, balita, ibu hamil dan untuk pelayanan keluarga berencana.

Sebenarnya pelaksanan posyandi di Kota Padang telah berjalan dengan baik.Selain melakukan penimbangan dan pemeriksaan kesehatan bagi bayi dan anak-anak, pada kegiatan posyandu ini, masyarakat (dalam hal ini ibu-ibu) diberikan pengetahuan mengenai gizi dan kesehatan keluarga.Namun, dari survei yang dilakukan selama penelitian ini, kurang terlihat partispasi yang optimal dari anggota masyarakat yang dijadikan sasarn.Oleh karena itu, diperlukan usaha yang lebih keras untuk menarik anggota masyarakat sasaran agar bersedia datang ke posyandu.
Salah satu cara yang mungkin dilakukan adalah dengan menyediakan makanan tambahan berupa makanan kecil ataupun hadia bagi bayi dan balita yang dibawa ke posyandu. Selain itu, posyandu dapat mengadakan kegiatankegiatan, seperti perlombaan-perlombaan untuk menarik masyarakat untuk datang ke posyandu. .

Untuk itu, tentu saja pemerintah kota melalui dinas kesehatan kota, perlu mengalokasikan dana tambahan. Dukungan dari anggota masyarakat ataupun dari perusahaan sekita (melalui Corporate Social Responsibility Programme) dapat diusahakan untuk tujuan ini.

\section{KESIMPULAN}

Berdasarkan hasil analisis, terdapat tiga variabel yang mempengaruhi status gizi balita di kota Padang yang dinilai berdasarkan indikator BB/TB. Ketiga variabel tersebut adalah usia balita, pendapatan keluarga dan pengetahuan ibu mengenai gizi. Ibu dengan pengetahuan gizi yang rendah akan memiliki peluang yang lebih besar untuk memiliki anak yang sangat kurus.

Salah satu cara untuk mengurangi prevalensi balita dengan status gizi sangat kurus adalah dengan meningkatkan pengetahuan ibu mengenai gizi. Salah satunya adalah melaui kegiatan posyandu.

\section{DAFTAR PUSTAKA}

Monteiro CA, Benicio MHD, Konno SC, Silva ACF, Lima ALL, Conde WL: Causes for the decline in child undernutrition in Brazil, 1996-2007. Rev Saude Publica. 2009, 43: 35-43.

Schroeder, DG and KH Brown (1994) 
Nutritional Status as a predictor of child survival : summarizing the association and quantifying its global impact. Bulletin of World Healt Organization 72(4) : 560-579

Kim. H \& W.-Y.Loh.(2001) Classification Trees with Unbiased Multiway Splits.Journal of the American StatisticalAssociation, 96:589-604.

Mazarina, D (2010). Analysis of Influential Factors on Nutritional Status of Under Fives in Rural Areas. Journal of Technology and Vocational, Vol. 33, No. 2, September 2010: 183-192

Kabeta,Aet.al. Factors Associated With Nutritional Status of Under-Five Children in Yirgalem Town, Southern Ethiopia. IOSR Journal of Nursing and Health Science (IOSR-JNHS e-ISSN: 23201959.p- ISSN: 2320-1940 Volume 6, Issue 2 Ver. V (Mar. - Apr. 2017), PP 7884

Rahmi, I.H.G dan H. Yozza (2013) Implementation of the QUEST Method to
Identify Accreditation Assessment Components Differentiating School Accreditation (Case Study of SMA / MA in West Sumatra).Journal of Mathematics Journal of Theory and Applied Mathematics). Volume 12 No. 1.

R. J. Lewis. 2000. An Introduction to Classification and Regression Tree (CART) Analysis. Annual Meeting of theSociety for Academic Emergency Medicine in San Fransisco, California.

World Health Organization (WHO). 2011. World Health Statistics. World Health Organization,Geneva, Switzeraland

Yohannes, Y. Webb, Patrick. 1999. Classification and Regression Trees, CART: A User Manual for Identifying Indicators of Vulnerability to Famine and Chronic Food Insecurity. Washington DC, U.S.A : Library of Congress Cataloging-in-Publication Data 